\section{Presymptomatic Detection and Early Diagnosis}

By the late C. L. E. H. Sharp and Harry Keen. Pp. xvi + 384, illustrated. London: Pitman Medical, 1968. £6 6s.

Steps taken to prevent the occurrence and spread of infectious diseases with other public health measures are very adequate in most developed countries and today's challenge to medicine is presymptomatic detection and early diagnosis of disease. This challenge changes the definition of medical care which apart from giving the best curative and symptomatic treatment with other supportive measures, now embraces routine screening of healthy subjects so that besides making an early diagnosis, individuals who are prone to common diseases like coronary heart disease, can be filtered out and given proper medical advice. Would such screening programmes create a nation of neurotics? Can we afford them? Are they practical? How often should the screening be done? These are a few questions which puzzle most clinicians and this book, which is written by a team of international experts and pioneers in this field, offers admirable and constructive views on the subject.

The late Dr Sharp has written a chapter on the 'Opportunities and Problems presented by Screening Procedures' and Professor C. H. Wood discusses the problems of underdeveloped countries. Every chapter is well written and is informative and I feel that this book should be read by everyone concerned with the future of medical care as early detection and presymptomatic diagnosis of diseases by screening is sure to play a big role in the life of future medical practitioners. It is, therefore, a great pity that the book costs $£ 66 \mathrm{~s}$, a price beyond the pocket of many medical students and, therefore, a good paperback is recommended.

\section{Chemotherapy of Chronic Bronchitis}

By J. Robert May. Pp. $x+115$, illustrated. London: The English Universities Press, 1969. £1 15s.

At first sight it may seem ridiculous to devote a whole book just to one part of the treatment of one disease. In fact it proves very satisfactory. The first half sets out clearly all the relevant information about the bacteriology of chronic bronchitis (much of it Dr May's own original work), and the available antibiotics. The second half gives a logical and practical account of the chemotherapy of the condition. The book should be read by all general practitioners and physicians-it is an easy evening's reading. General practitioners will find it valuable because it shows how efficient treatment can be carried out without bacteriological aid. For physicians it is important because it should serve to diminish the unrewarding and wasteful demand they impose upon laboratories.

The one shortcoming of the book is that it was written before the value of the trimethoprim sulphamethoxazole combination could be fully assessed.

\section{Lectures in Medicine}

By C. W. H. Havard. Second edition. Pp. xiv +399 , illustrated. London: Staples Press, 1969. £3 10s (paperback f2 5s).

I welcome this second edition of Lectures in Medicine. The success of the first edition made it essential that a second edition should follow without too long an interval and we can welcome it in its own right.

The general plan of the book is the same as before. Four chapters have been excluded and the whole text has been revised to make it up to date. Two new chapters on 'Adrenergic Receptors' and 'Medical Aspects of Transplantation' appear in this edition. Both are well written and give a wealth of useful information on the subject. I am sure this second edition will prove as popular as the first one and can be recommended without reservation.
ABC of the E.C.G. A Guide to Electrocardiography

By J. Boutkan. Pp. viii +204 , illustrated. Philip's Technical Library. The Netherlands: Centrex Publishing Company (distributors in the United Kingdom and Eire, Macmillan, London), 1969. £2 6s.

This book admirably explains the electrophysiological phenomena and physics of electrocardiography, and the reader will soon learn how the normal and abnormal electrocardiographic tracings originate. There is a chapter on vectorial representation of the electrical heart activity and two chapters on the normal electrocardiographic leads, configurations and valves. Abnormal electrocardiographic pattern in bundle branch block, auricular and ventricular hypertrophies, coronary artery disease, Wolff-ParkinsonWhite syndrome and various arrhythmias are perfectly illustrated and described. There is also a useful chapter on effects of drugs and electrolyte imbalance on the ECGs.

The book is well produced and in spite of the wealth of literature on the subject it fulfils the author's wish, that is, that the reader will be able to form a correct judgement of routinely occurring ECGs and to evaluate them according to clinical significance. It can be recommended to the initiate as well as to the experienced clinician.

\section{Victory with Vaccines}

By H. J. Parish. Pp. ix + 245. Edinburgh and London:

E. \& S. Livingstone, 1968. $£ 110$ s.

Dr Parish modestly claims to be a historian of only amateur status but this book is clearly written by a master of his subject who also has the power to convey the excitement, and at times the despair, of those early pioneers and their successors in the fascinating story of the overthrow of infectious diseases by immunization.

Victory with Vaccines is a semi-popular version of his History of Immunization. It traces the origins of the fight against infectious diseases from the oldest form of artificial immunization 'variolation' to the highly scientific procedures we use today and does it in terms which can readily be understood by the lay-man and at the same time appreciated by the professional. Behind this facade of 'popular' reading is a fund of information, scientific explanation and philosophical appraisal of the past, present and future.

The author has purposely omitted any discussion of immunological reactions involved in organ transplantations and autoimmune diseases, but he covers a vast field of infectious diseases. In order to keep down costs there are no illustrations but the text is clearly printed and most readable. There are some immunization schedules including two recommended for international travel which should prove a valuable guide for doctors and travellers. The bibliography is short but some splendid biographical notes are appended, supplementing the coverage already given in the text to many distinguished scientists from all parts of the world.

This book will fascinate anyone interested in medical history, and should prove a stimulating and valuable guide to those concerned in the ever-expanding field of preventive medicine.

\section{Illustrated Manual of Laboratory Diagnosis}

By R. Douglas Collins. Pp. 299, illustrated. London: Pitman Medical; Philadelphia: J. B. Lippincott, 1968. £10 10s.

This lushly produced guide to clinical laboratory diagnosis provides a useful and concise summary of a great deal of information. Some, however, is inadequate, notably that given for isotope investigations of thyroid function (only the 24-hr uptake of ${ }^{131}$ I is mentioned: not the other uptakes or the use of ${ }^{132}$ I or of suppression). The red cell uptake of $T_{3}$ is described but nobody uses this now when resin is available.

The cost of the book has been vastly inflated by the numerous coloured diagrams which, in the opinion of this reviewer, add very little to its value though they are a gimmick that may help some readers to grasp the significance of the tests and to remember them. 